\title{
光ファイバを利用した建築化照明 \\ Structural Lighting of Light Fiber
}

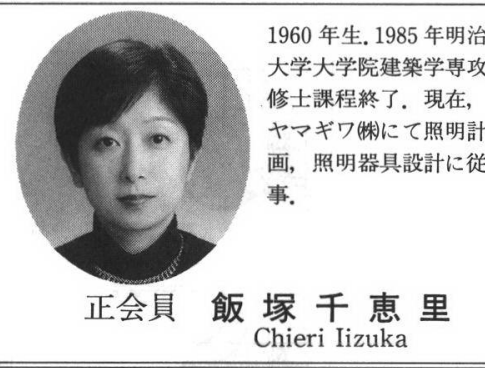

\キーワード：光ファイバ，建築化照明

Chieri Iizuka

\section{1.はじめに}

近年，光ファイバを利用した照明施設が増加してきて いる．照明の分野では，初期の使用法は端部発光を利用 したいわゆる星空天井が多かったが，ファイバと光源装 置の開発と改良によって，現在ではさまざまな使用法が 試みられている。

ここでは，光ファイバの特性，建築化照明の分野にお ける光ファイバの開発動向と, 光ファイバを利用するこ とのメリット，計画の手順と使用する場合の留意点につ いて紹介していく.

\section{2. 光ファイバの特性}

\section{1 光ファイバの種類}

光ファイバを素材で分類すると，ガラス系ファイバと プラスチックファイバに分けられる。照明用に使用され るガラスファイバは，さらに石英ガラスを使用したタイ プと多成分系ガラスを使用したタイプに分けられ，その なかでもさまざきな性能，特性を持つグレードがある. また，プラスチックファイバは小口径ファイバと大口径 ファイバに分類できる（図1）。

ガラスファイバの 1 本の直径は，数 $10 \sim 1000 \mu \mathrm{m}$ （1 $\mathrm{mm}$ ）程で，それを数十 数万本束ねた数ミリ径のバン ドルとして使用する，プラスチックファイバも，小口径 (0.2 2 mm) のものは, 数本〜数百本を束ねて使用す

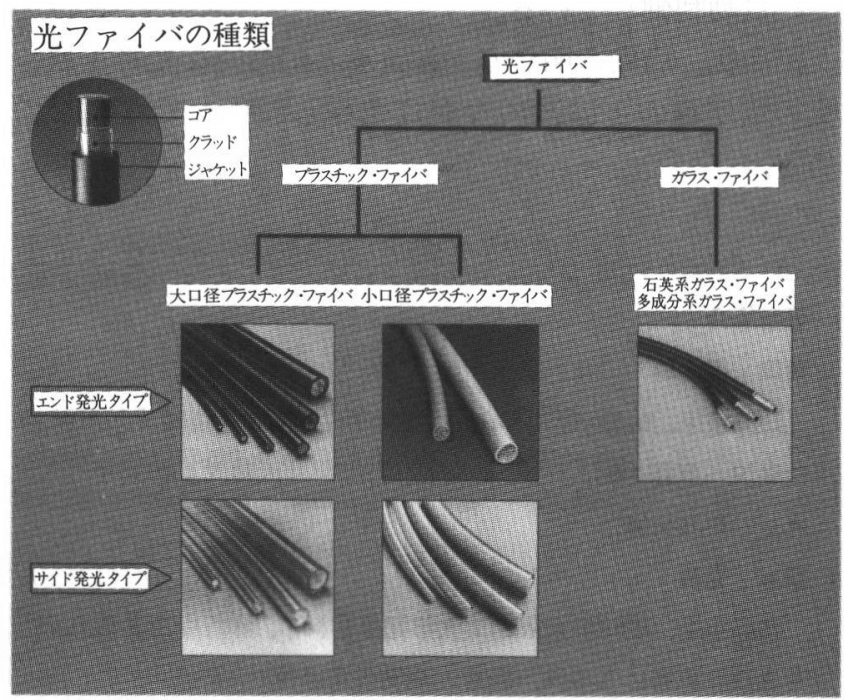

図1 光ファイバの種類
るのが一般的だったが, 近年, 大口径 $(2 \sim 20 \mathrm{~mm})$ のプ ラスチックファイバが開発され，入射効率のよさに伴う 照度アップによって建築化照明の分野に普及しつつあ る.

\section{2 各種ファイバの伝送損失}

光ファイバをライトガイドとして使用した場合，ファ イバが長くなるほど光量は減っていき，長さと減光率は ほぼ比例関係にある，減光率は石英ファイバが最も少な く，ついで多成分系がラスファイバ，プラスチックファ イバの順となる。プラスチックファイバの場合で, $10 \mathrm{~m}$ 引き回すと光量は入射時の約 $40 \sim 50 \%$ となる. 光の各波 長域ごとの透過率はファイバの種類によって異なり，長 いファイバを通った光は色味に変化が生じる（図2）.プ ラスチックファイバの場合は, 赤い波長域の透過率が低 いため，長距離を引き回していくと出てきた光は緑色に シフトしていく．多成分ガラスファイバの場合は紫の波 長域を吸収するため, 光は黄色にシフトしていく。また， コアとクラッドの境界で反射していく際に赤い波長域が 吸収されるため, 照射された光のビジュアルエッジ（光 の外周）に若干青色が見える．石英がラスファイバは， 可視域全般に渡り透過率がフラットであるため, 色のシ フトはほとんどない.

\section{3 耐熱性能}

光源からファイバに光を入射させる時，入射面の耐熱 温度は，プラスチックファイバでは約 $70^{\circ} \mathrm{C}$, 多成分お

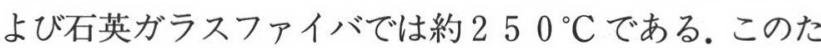
めより強い光をファイバに通そうとする時には, 耐熱温 度の高いガラス系ファイバが有利となる，光源装置側で

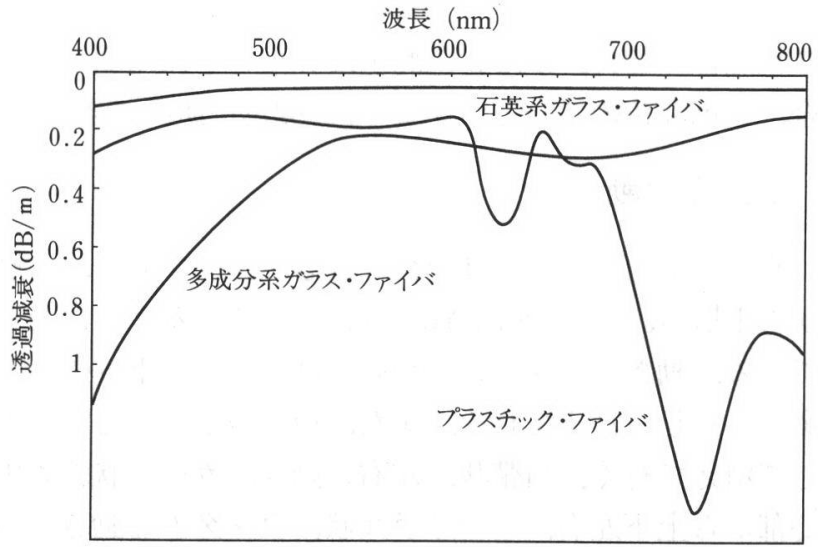

図 2 各種ファイバの透過率 
はダイクロイックミラー反射鏡の使用や，熱線吸収ガラ スなどで熱線をカットしている。

\section{4 対衝撃性}

ガラス系ファイバの場合には, 屈曲を繰り返したり外 部から衝撃が加えられると，バンドル内部で折れてしま うことがある。そのような可能性がある場合は，保護の ためにフレキ管使用のファイバを使う必要がある。プラ スチックファイバは，比較的屈曲や衝撃には強いため, 樹脂系の被覆材の場合が多い.

\section{5 コスト}

単純に素材としての単価を比較すると，プラスチック ファイバ，多成分ガラスファイバ，石英ガラスファイバ の順に高くなる。ただし，透過効率や耐熱性能の違いか ら，同一照度を得るためのファイバ総量は異なるため, コスト比較は単純ではない.

\section{6 配光}

おおむねプラスチックファイバでは, 発光端部から出 る光の広がりは約 $60^{\circ}, 1 / 2$ ビ一ム角は約 $30^{\circ}$ である.

ガラス系ファイバの場合は, 石英ガラスファイバの広 がりが約 $45^{\circ}$, 多成分ガラスファイバでは組成の違いによ り $30^{\circ} \sim 70^{\circ}$ 程度のバリエーションがある. 発光端部には レンズ付き器具を接続させることも多く, 配光はかなり 自在に制御することが可能になってきている.

\section{3. 光ファイバの開発動向}

次に，とくに近年開発されてきた新しいファイバを紹 介する。総じて現在は，より強く明るい光を得るための 開発が目立ち，建築化照明に適したファイバのバリエー ションが増えてきている。

\section{1 大ロ径プラスチックファイバ}

大きなコアを持つ大口径ファイバは，効率よく光を入 射するという点で非常に有利である，有効受光面積を比 較した場合，大口径ファイバはコアがソリッドのため, コア径がそのまま有効受光面径となるが，バンドルファ イバでは束ねた小口径ファイバの間にすき間ができる。 この結果大口径ファイバの有効受光面は小口径ファイバ をバンドルしたものに比べて1.5〜 2 倍の面積となり， これが入射光の差になる．透過率（出射光束/入射光束） を比較した場合，素線（1本当たり）ではガラスファイ バがプラスチックファイバにまさるが，バンドルした製

\section{(a)大口径ファイバ}

(b)バドル・タイプ・ファイバ
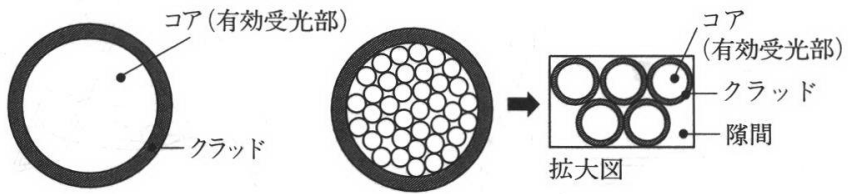

図 3 大ロ径プラスチックファイバとバンドルファイバの 断面比較
品で比較した場合には短距離においては大口径ファイバ がガラスファイバを上回る（図３）.

このタイプは, 現場での長さ調整やカットが可能なた め，施工面でのメリットもある。大口径ファイバの開発 により，建築スケールでの照明器具としての沉用性が高 まったといえる.

\section{2 強力サイド発光ファイバ}

プラスチックファイバには, 先端で発光するエンド発 光タイプと，側面全体が発光するサイド発光タイプがあ る(図 $4(a))$. 近年サイド発光でも，より高輝度の夕イプ が開発され，それまではチューブ状に発光する輝度を見 せることに目的をおいていたものから，間接照明など照 度を必要とする使用法にも活用できるようになってきて いる。.さらに一方向だけに発光する強力サイド発光夕イ プ (図4(b)) は, 大口径ファイバに特殊加工を施し, かつ てない程の高照度を得ることができるようになってき た。

サイド発光夕イプの場合，片側から光を送る場合は 10 $\mathrm{m}$ まで, 最大引き回し長さは $30 \mathrm{~m}$ まで可能だが，その場 合は両端から光を送ることにより均斉度を高めることが できる(図 5 )。

\section{4. 建築化照明に利用するメリット}

このように選択が多様になってきた光ファイバを建築 化照明に使用する場合のメリットについて考之てみる。

\section{1 メンテナンスが難しい場所への設置の場合}

建築の外壁面など，高所でランプメンテナンスが困難 な場所でファイバを利用すれば，室内側や低い位置での メンテが可能となり，ランプ交換時に足場を組むなどの 経費や人的手間を少なくすることができる. 光ファイバ の発光部は電気的にフリーであること，発光部に光源を 持たないことから，外構で使用する場合は施工時の雨じ まいが楽である.ささら発光部は水没しても何ら問題が ないため，水中での使用に対しても漏電などの心配がな w.

山口県の秋吉台国際芸術村（建築設計：侏磯崎新アト リエ）本館棟中庭，パフォーマンスステージ周囲の床面 に設置された光ファイバは，前面にフロストガラスを取 り付け，柔らかな52ポイントの発光面がグリット状に配

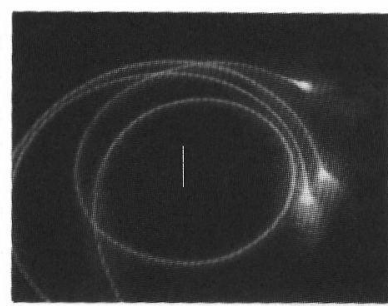

(a)

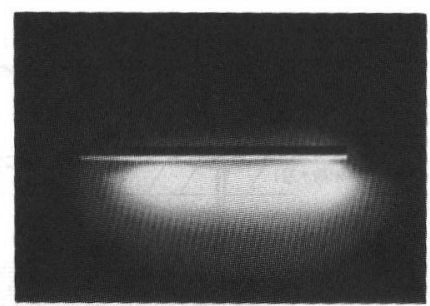

(b)
図 4 サイドライトと強カサイドライト 
置されている(図6).

玉砂利敷きの床面は公演時には水が張られ，中庭を囲 む施設の照明が映り込み幻想的な雾囲気を醸し出すが, 通常時は水が張られない. 一般の水中照明は水没してい ないと点灯できないため, 光ファイバを使用した水陸両 用照明が考案された。メンテナンスは階段下機械室の光 源装置（ハロゲンランプ175W， 6 分岐，9台）側で行え る(図7).

\section{2 器具設置場所が十分取れない場合}

設置環境が, 通常の照明器具を取り付けるほど寸法が 取れない場合, ファイバの発光端部寸法は, $30 \sim 50 \mathrm{~mm} \phi$ 程度と小さく, さらにバンドルファイバを直接建築に施
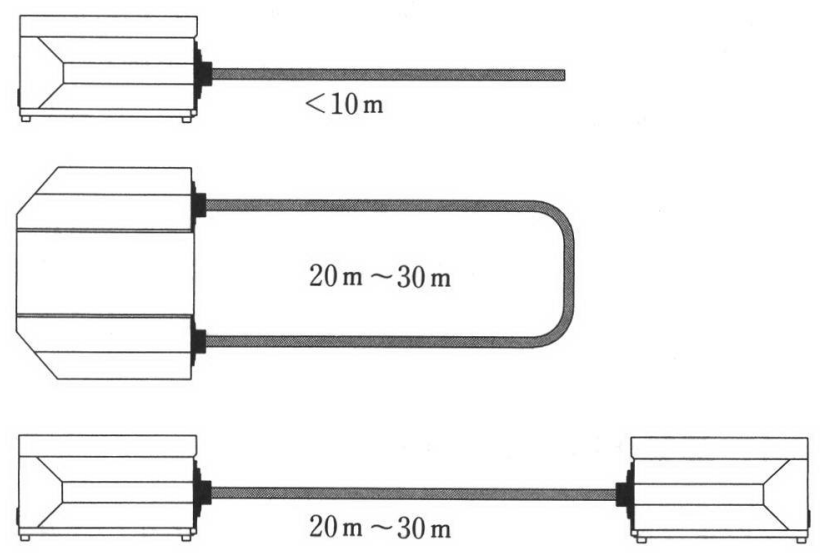

図 5 サイドライト引き回し参考図

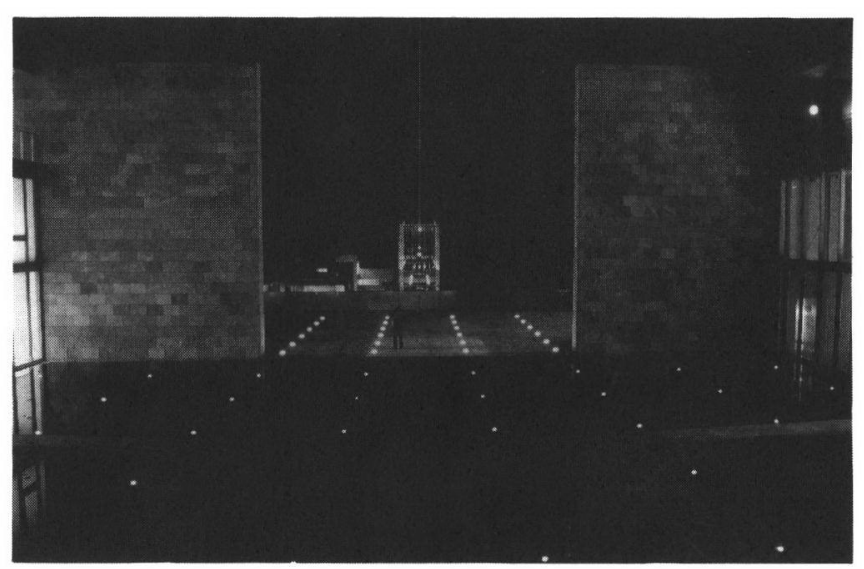

図 6 秋吉台国際芸術村 本館棟

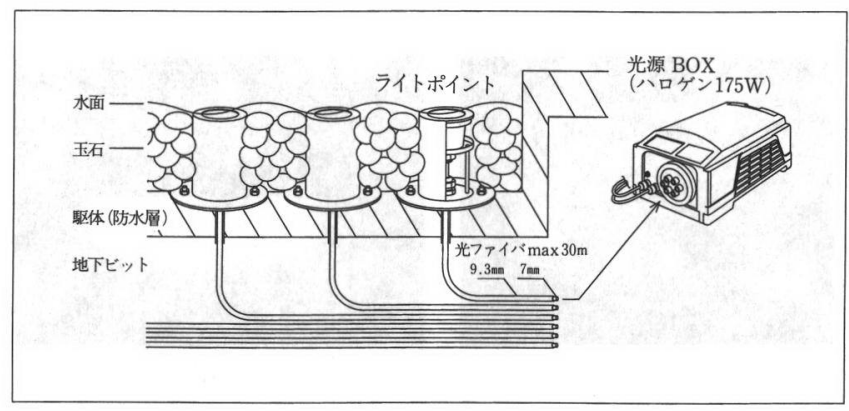

図 7 照明器具システム図
工すれば，寸法はファイバ径+ $\alpha$ ですむことになる（図 8)。また, 小口径ファイバを束ねる場合は, 先端形状を 自由に作ることができるため, 数 $\mathrm{mm}$ 幅のスリットから リニアに光を出すような形状も可能である.

\section{3 温湿度環境に影響を与えたくない場合}

ファイバの光源装置では光源側で紫外線, 赤外線を カットしているので, 発光端部やファイバ全体からの発 生熱量が非常に小さい。このため美術館・博物館の展示 ケースに使用されることが多いのだが，建築空間でも室 内全体の温湿度環境に照明で影響を与えたくない場合, たとえばワイン貯蔵庫などでの使用や, ショーケースで の使用, 被照射物が温度変化や湿度の低下に敏感な場合 に有効である。

\section{4 モデリングに自由度を与えたい場合}

固定された立体物を照射する場合, 形状によっては上 方からの光だけではどうしても除影ができてしまうこと がある。この場合通常のスポットライトなどの照明器具 が設置できない場合でも，ファイバ発光部の大きさであ れば器具の存在をほとんど感じさせずに発光部を設置す ることができる，床面，壁面，設置台などから自在な角 度で光を当てることができるため, 超小型スポットライ トとしての利用価値は高い（図9).

また建築的にコーブ寸法が取れない，あるいは器具を 露出させたくないなどの理由から，スポットライトの代 わりにファイバにより間接照明をすることができる，基 本的にファイバからでる光は集光性があるため, 素材の テクスチュアや立体感を出すのに適している，最小の寸 法から最適な方向に光を与えることができる.

\section{5. 計画の手順}

次に建築空間に光ファイバを使用するときの, 計画の 手順と留意点について考える.

\section{1 必要とする光を検討し, ファイバ種類を決定}

建築上のどのような位置にどのような光が必要とされ るのかを検討し, 使用する光ファイバの発光タイプと使 用するファイバの素材を検討する。この時点では予算上 の検討も行われるため, コストも考慮して使用する光の 品質や照度の要求に応じて選択する必要がある．照度 データから必要とされるファイバの直径を検討し，照度
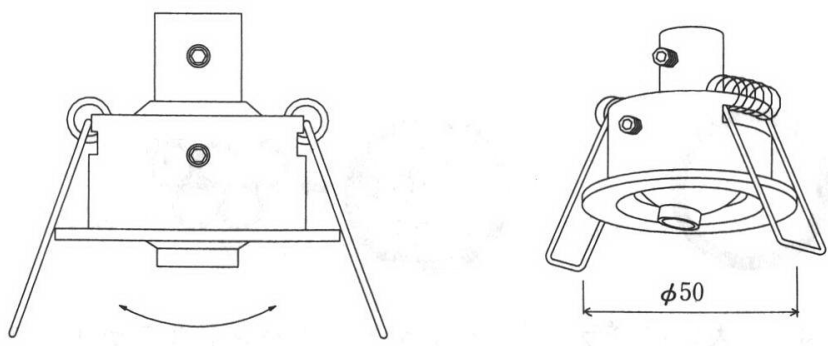

図 8 光ファイバ発光端部 


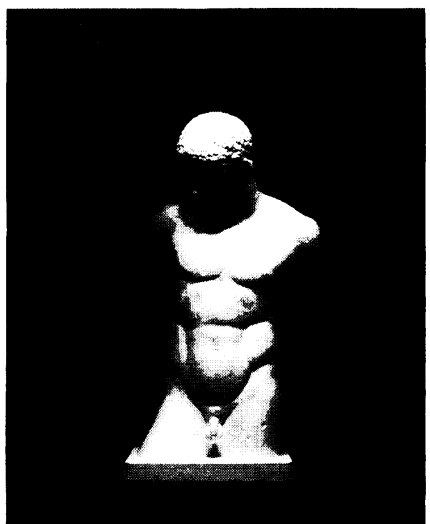

(a) 上方からの光のみ

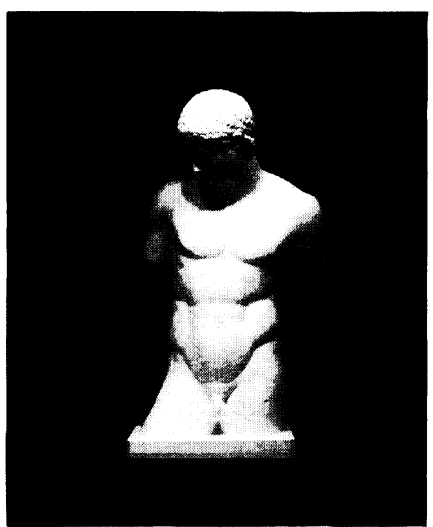

(b) 上方+下方からの光

図 9 モデリング実験

分布を想定して取り付けピッチを決定する.

\section{2 発光部形状の決定}

建築取り付け環境から，発光部の形状を検討する，心゙ ンドルファイバの場合，通常の断面形状は円形だが，設 置環境の与条件によっては形状をライン状にするなどの 加工が可能である.

\section{3 光源装置の台数の決定}

必要照度とファイバ総本数の決定により, 光源装置の 光源の種類，ワット数を決定する．現在光源としては, ハロゲンランプ，メタルハライドランプ，キセノンラン プが主に使用されている. 美術品照明など, 光の分光分 布や演色性が問題とされる場合には八ロゲンランプを光 源として選択するが，より高照度を必要とする場合や高 い色温度を使用したい場合には,メタルハライドランプ, キセノンランプを選択する，通常は光源装置側で 1 本に 束ねたファイバを分岐させて引き回すが, 光源装置に差 し込めるファイバ直径には限界值があり, 必要とする発 光部の個数から光源装置の台数が算定できる. また, 光 源装置によっては内部に分岐させるためのレンズが内蔵 されているタイプもあり，この場合には分岐数が設定さ れている.

\section{4 光源装置の設置場所を決める}

光源装置の設置場所を検討するに際しては，天井の場 合には点検口の近く，屋外から室内へ引き回寸場合には 機械室などが考えられるが，いずれの場合も発光部の光 量はファイバ長に比例して減光していくため, ファイバ の設置場所からできるだけ近くが望ましい.

\section{5 ファイバ長を決定する}

光源装置から各発光部取り付け場所までの距離でファ イバ長が決まるわけだが，とくに天井内部などを引き回 していく場合には途中に障害物がないか確認し, 必要最 小寸法か望ましい。

\section{6 取り付け環境の検討}

ファイバは最小曲げ半径が決まっており，それを越え て強い力が加わると漏光して減光したり，ガラスファイ バの場合にはバンドル内部で折れてしまうこともある。 天井裏で引き回す場合などは, 発光部に自重で曲げモ一 メントがかからないように支持金物で押さえるなどの配 慮が必要とされる。そのため天井設置の場合は取り付け やメンテナンスのためにも天井裏に寸法的な余裕が必要 となる．また，光源装置には光源のワット数により空冷 ファンが設置されているが，天井裏に光源装置を置く場 合などは，光源装置を直接天井面に置くとファンの振動 が天井に共鳴して思わ騒音になってしまう場合があ る、スラブからボルトで吊る, 光源装置の下に制震ゴム を敷くなどの対処が必要である．現在光源装置の空冷 ファンの発生音は, 静音夕イプのファンを使用するなど 改善され, $12 \mathrm{~V} 100 \mathrm{~W}$ ハロゲンランプ光源装置の場合で, 27デシベル程度となっている.

また光源装置から発熱するため, 設置場所周辺は空間 を取り，空気の循環する設置環境か望ましい。

\section{6. 終わりに}

「建築に調和した照明」というテーマに沿って光ファ イバという素材を解説してきたが, 現在ファイバは第 2 世代に入ってきている．すなわちイルミネーションとし て輝度を見せていた使用法を第 1 世代として, 今後はよ り照明器具としての使用法が確立され, アプリケーショ ンの開発，改良が進むと考えられる，加えてファイバの 照度デー夕, 演色性などの技術資料を整えていくことで, 一般の照明器具と同列に検討されていくと考之られる. しかしここで大切なことは，ファイバという素材が必要 とされる必然性がなければコストバランスのなかで害現 は厳しいということである。真に建築に調和した照明と は，照明をきれいだと感じることではなく，建築が美し いと感じられたときに成立するものであり，必然性の結 果選択された素材が，その意義を全うしたときに初めて 調和が得られるからである。 